\title{
Characteristics of selected elements of the air quality management system in urban areas in Poland
}

\author{
Izabela Sówka ${ }^{1, *}$, Dominik Kobus ${ }^{2}$, Anna Chlebowska Styś ${ }^{1,3}$ and Maciej Zathey ${ }^{4,5}$ \\ ${ }^{1}$ Wroclaw University of Science and Technology, Faculty of Environmental Engineering, Unit of \\ Ecologistics and Environmental Risk Management, 50-370 Wroclaw, Wyb. Wyspianskiego 27, \\ Poland \\ ${ }^{2}$ Institute of Environmental Protection - National Research Institute, Air Quality Monitoring \\ Division, 00-548 Warsaw, Krucza 5/11d, Poland \\ ${ }^{3}$ Voivodship Inspectorate of Environmental Protection in Poznan, 61-625 Poznan, Czarna Rola 4, \\ Poland \\ ${ }^{4}$ Wroclaw University of Science and Technology, Faculty of Architecture, Department of spatial \\ planning and settlements processes, 50-317 Wroclaw, B. Prusa 53/55, Poland, \\ ${ }^{5}$ Institute for Territorial Development, 50-527 Wroclaw, J. Wl. Dawida 1a, Poland
}

\begin{abstract}
Most of Europeans living in cities are exposed to concentrations of air pollutants in excess of the thresholds given in the WHO guidelines and EU legislation. Due to this fact, for the urban air quality systems, the mechanisms of proper information and warning of the inhabitants as well as legal, economic and spatial planning instruments should be improved. The analysis of Polish air quality management system and its' selected components (exemplary measures, information-spreading methods, spatial planning instruments) in four selected Polish cities (Wroclaw, Warsaw, Poznan and Cracow) indicated the need to develop effective solutions, among others, in terms of: emission requirements for combustion of fuels of power of up to $1 \mathrm{MW}$; admission of high emission fuels on the market; legal and coordination issues at the level of implementation of the area development policy and coordination of activities covering issues within the scope of the structure of planning documents including mainly: ambient air protection programs, spatial developments plans in communes and voivodeships, low emission economy plans, plans of sustainable development of public transport, plans of providing heat, electric power and gas fuels to communes, acts of regional parliaments, introducing limitations based on the Environmental Protection Act and strategies of voivodeship.
\end{abstract}

\section{Introduction}

Information provided by the World Health Organization (WHO) describes the negative impact of air pollution on human health $[1,2]$ and indicates that most of Europeans living in

* Corresponding author: izabela.sowka@pwr.edu.pl 
cities are exposed to concentrations of air pollutants in excess of the thresholds given in the EU legislation and WHO guidelines [3]. Therefore, managing and caring for air quality, especially in urban areas, are one of the current challenges for EU countries.

Urban air quality management (UAQM) is defined as a system that can establish a robust and integrated environmental management life cycle for urban areas of interest; a system that focuses on local actions to deal with urban hot spots of air pollution; activities that identify specific pollution hot spots on the basis of advanced and complex air-quality dispersion modelling and monitoring techniques; and as activities carried out by the government, business entities, industry, NGOs and the society that helps in attaining air quality goals in a specified geographical area [4]. Those activities, which have been carried out for many years, cover conceptional studies on, among others: Air Quality Monitoring Programs (AQMP) as programs aimed at ensuring control of emissions in order to protect the public health and welfare and as systems for designing and implementing monitoring and management activities as well as policies within an urban area, an integrated methodological scheme for evaluation of air pollution control measures schemes, Local Air Quality Management Plans (LAQMP) focusing on the distribution of power at the community level and strong communication and cooperation between entities participating in air quality management, temporary Urban Air Quality Management Plans (e-UAQMP), and software tools. The basic elements of an air quality management system are: air objectives/quality standards (NAAQS), air quality monitoring standards (NAAQM), source apportionment (SA), emission inventory (EI), UAQM strategies, assessment of air pollution exposure and its influence on health and activities carried out by the public. Implementation of UAQM results in creation and introduction of legal provisions to international legal systems, which concern, among others, local and regional areas (or a city) and creation and implementation of programs as well as development of strategies related to, among others, road transport, including: stringent emissions norms, alternative fuels in vehicles, improvement in fuel quality, fitting catalytic converters, use of low and zero emission vehicles, support for cycling, bus lanes, low emission zones, intelligent transport systems, subsidies for registration tax applicable to environment-friendly vehicles, maintenance of road infrastructure [4,5]. The final stage of their application aims at the reduction of pollution emissions and brings benefits to urban residents, such as improvement of the air quality in urban areas, a lower number of hospital patients suffering from bronchitis and asthma and an increase in the average life expectancy $[4,6]$ that are related to it. Thus, it is important that local and national actions are synergic and integrated and that they aim at construction and optimization of an air quality management system, whose synchronized and multi-level operation could eventually result in improved air quality and improved well-being for residents of Polish cities.

The paper shows the characteristics of air quality systems and their exemplary components (exemplary measures, information-spreading methods, spatial planning instruments) applied in selected four Polish cities: Wroclaw, Warsaw, Poznan and Cracow. Shortcomings and proposed measures for improvement of the existing national system of air quality management are also described.

\section{Examples and elements of urban air quality management system in Poland}

\subsection{Air pollution standards and monitoring}

According to the Environmental Protection Act (POŚ), [7] agglomerations and big cities (with more than 100,000 residents) constitute zones in which the air quality assessment is 
carried out in relation to the health of their residents. The remaining zones consist of voivodeships, with the exclusion of those with more than 100,000 residents and agglomerations, for whom the air quality assessment is done in order to protect health and plant life. The assessment in terms of human health takes into consideration the content of $\mathrm{SO}_{2}, \mathrm{NO}_{2}, \mathrm{CO}, \mathrm{C}_{6} \mathrm{H}_{6}, \mathrm{O}_{3}, \mathrm{PM}_{10}$ and $\mathrm{PM}_{2,5}$ particulate matters, heavy metals (As, $\mathrm{Cd}, \mathrm{Ni}, \mathrm{Pb}$ ) and benzo(a)pyrene in $\mathrm{PM}_{10}$. The aforementioned types of pollution were assigned limit, target and long-term (in case of ozone) levels of concentration in the air [8]. Due to the significant harmfulness to health of $\mathrm{PM}_{2,5}$ particulate matter, standards concerning exposure of residents of big cities and agglomerations to $\mathrm{PM}_{2.5}$ particulate matter have been conducted [9]. Short time exposure to very high levels of air pollution can cause serious damage to the human body, and that is why Polish law establishes appropriate alert levels. Information levels have been also established for $\mathrm{PM}_{10}$ particulate matter and $\mathrm{O}_{3}$. An information level is a level of concentration of a given substance in the air, which if exceeded, can cause a threat to human lives resulting from a short exposure of sensitive groups of people to pollution, and that is why it has to be immediately and appropriately announced to the public. An alarm level means that there is such a concentration of a pollutant that if exceeded even for a short time, it can be life threatening. Those levels have been established for $\mathrm{O}_{3}, \mathrm{PM}_{10}, \mathrm{SO}_{2}$ and $\mathrm{NO}_{2}$ [8].

Air quality monitoring is carried out in Poland by Voivodship Inspectorates for Environmental Protection (WIOS) in accordance with Voivodeship Environmental Monitoring Programs. Supervision over the State Environmental Monitoring (PMS), as part of which measurements referred to in the Voivodeship Programmes are carried out, is maintained by the Chief Inspectorate for Environmental Protection (GIOS). Measurements of pollutant concentrations are done according to referential methodologies indicated in [10]. The results of the measurements at the Voivodeship level are then submitted to the database of GIOS (JPOAT2.0 database). After measurements are accepted at the Voivodeship level, the data is subjected to analysis and selection in terms of compliance with established criteria and possibilities of their use for annual air quality assessment.

Measurement of air pollution belong to the responsibility of WIOS appropriate for the given territory and are supervised by the National Reference and Calibration Laboratory (KLRiW) of GIOS, which belongs to the Air Quality Reference Laboratories (AQUILA). The main tasks of KLRiW are: maintaining reference standards, calibration of analysers, carrying out audits in monitoring stations, carrying out national intercalibration of particulate and gas meters, organisation of training courses and implementation of new measuring and research methods.

The quality of air in cities is established on the basis of measurements carried out by WIOŚ, complemented by mathematical modelling and estimation methods. There are two types of measuring stations on urban territories - background and traffic stations localised in the direct vicinity of roads with high traffic. Their aim is to study the impact of road transport.

During the winter season, Polish cities are faced with problems such as, among others, increased concentration of particulate matters and benzo(a)pyrene and that is why, for the needs of the paper, their annual concentration values between 2010-2016 (Fig.1) were averaged, and daily average of $\mathrm{PM}_{10}$ concentrations were compiled (Fig. 2). The annual and daily average values were obtained thanks to measurements done by urban background and traffic stations, located in the following cities: Poznan, Wroclaw, Cracow and Warsaw. The analysis of results of concentration measurements indicates (Fig. 1) that since 2010, $\mathrm{PM}_{10}$ particulate matter concentrations are decreasing, even though they are at a level exceeding allowed standards (Cracow traffic and background and Warsaw traffic stations) or are close to the allowable value (Warsaw background, Poznan background and Wroclaw background stations). In some stations, the standard for annual average concentration was exceeded 
(Fig.1), however, this happened mainly in case of average daily concentrations (Fig. 2). The highest concentration levels were found to be present in Cracow and Warsaw. In case of Cracow, this results mainly from the geographical localisation of the city, which makes ventilation of premises impossible, and combustion of fossil fuels like coal (often with low quality) in the residential sector. In case of Warsaw, especially in it central area, increased car traffic plays an important role. High concentration of $\mathrm{PM}_{10}$ in the air results in high concentration of one of its components: benzo(a)pyrene. Every year, in all cities studied, the concentration of this substance was above the standard, and the highest concentration was found in Cracow, which was slightly lower in Wroclaw and Poznan, while the lowest in Warsaw (Fig. 1). Due to the above, it can be concluded that what influences the air quality in Cracow, Wroclaw and Poznan is combustion of fuels in the residential sector, while in case of Warsaw it is the road traffic. The measurements of PM10 concentration in 2015 carried out in urban background stations (Fig. 2) show clearly that there is a seasonal variety of $\mathrm{PM}_{10}$ concentration in the air. Higher concentrations occur in autumn and winter, and this clearly shows the influence of the residential sector on the quality of air in the analysed cities.
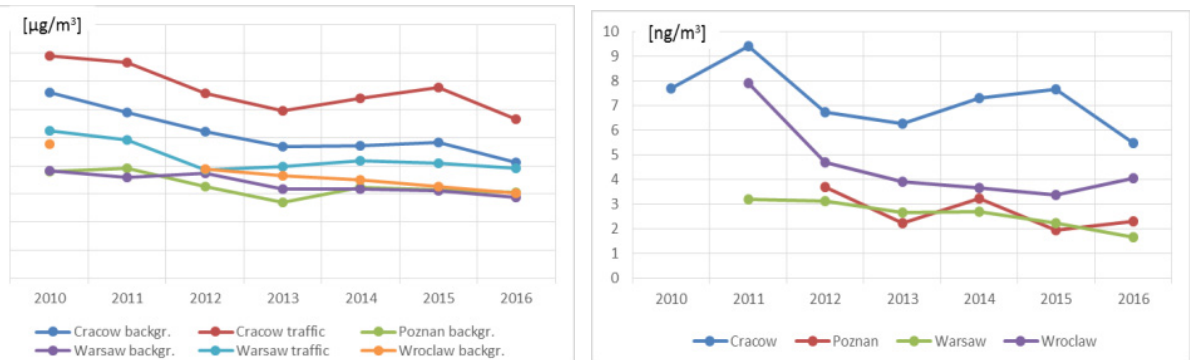

Fig.1. Averaged $\mathrm{PM}_{10}$ (left) and Benzo(a)pyrene (right) annual mean [source: own elaboration based on PMS/ GIOS data]

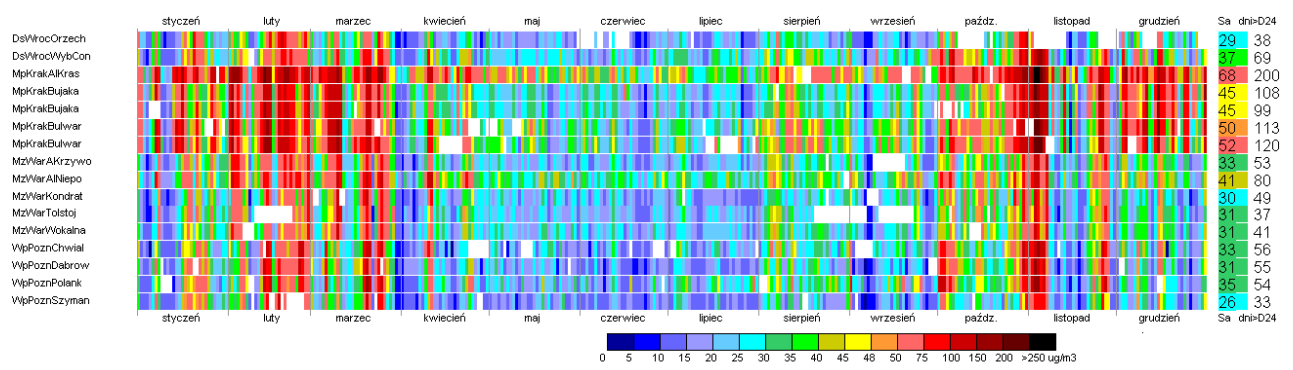

Fig. 2. Daily averages of $\mathrm{PM}_{10}$ concentration in 2015 [source: as above]

\subsection{Information-spreading methods}

Information about the air pollution level is an important element of an urban air quality management system. It is related to fulfilment of legal obligations towards selected public institutions. Those obligations are included in both international acts [11, 12], and national documents [13]. Another factor that contributes to it is the social need for reliable and current information on the quality of chosen components of the environment, including ambient air. An important aspect is also the educational significance of information and its possibility of shaping chosen behaviours of its recipients, such as the choice of a mean of transport [14].

Information systems involve, among others, publication of reports on measurement results and assessment of air quality, presentation of the current state and forecasts 
concerning air quality for the next few days. The last two elements have an informative and alerting function, which, apart from the decisive and management or the forecasting and planning function are the main purpose of operation of public information systems [15].

Information about the quality of air is provided at different levels and with varied amount of details. At the national level, GIOS operates an information system based on data coming from monitoring stations, which belong to the PMS network, and forecasts of future ozone concentration [16]. WIOS, using their websites, present information concerning their voivodeship area [17-20]. Data presented by units which are officially involved in PMS are subject to strict quality assurance and quality control (QA/QC) requirements related to, for example, the use of reference measurements or equal methods, calibrating and intercalibrating systems, supervision and multi-level assessment of the results as well as assessment of the station's localisation in terms of its representativeness and compliance with the rules.

Information systems are needed the most in situations where the content of a given substance is the highest and thus, the social interest is also the highest. That is when warning messages are published with information on potential health consequences and recommendations, especially for those belonging to sensitive groups. As part of short-term activities plans adopted for Warsaw, Cracow, Wroclaw and Poznan, procedures concerning information activities taken in case of the need to make announcements were established for every level. The level of the alert (from I to IV) depends on the observed (exceeded) or forecasted (risk) pollution concentration in the air. For example, the action plan for Warsaw concerning exceeded ozone concentrations establishes the following procedure of passing information: the Mazovian Voivodeship Inspector for Environmental Protection informs the Voivodeship Crisis Management Team (WZZK) and the Mazovian Voivodeship Management. WZZK then informs the President of the capital city of Warsaw about the incident, and the President submits the information to organisational units of the capital city of Warsaw, including the Crisis Management Team of the capital city of Warsaw. The latter informs local media, local rescue services, hospitals, educational establishments, entities and institutions obliged to act and the society. Procedures adopted for other cities and applicable to other types of pollution are similar.

Selected cities create their own local information systems that are a part of an urban air quality management. One of such cities is Warsaw, which is working on its Warsaw Air Index (WIP) supposed to consist of an algorithm for processing and presenting measuring data from PMS stations and a local network of several non-reference sensors independent from them [21]. The WIP is also supposed to include a prediction system generating information for the city residents as well as supporting the process of making management decisions in the city.

\subsection{Spatial planning instruments}

Pursuant to the Environmental Protection Act [7], the basic instruments intended got air protection in Poland are regional programs of air protection (POP), which establish their aims, but do not include any financing or control measures. It is also possible to adopt a resolution introducing limitations concerning fuels and fuel combustion systems.

On the basis of the act on spatial planning and management of voivodeships, it is possible to create functional zones and define the rules of spatial development for them [22]. This can be done on the territory of, among others, a capital of a voivodeship and its surroundings - the city's functional zone. Those regulations can also concern another type of a functional zone, for example mountain areas - that are territories which are distinguished by their morphology, transport access and, very frequently, loss of their function. A local spatial development plan can also include arrangements concerning 
thermal energy by way of indicating sources of heat energy. It can also cover emissions of equipment in relation to heating capacity. In addition, the plan can establish protection zones and introduce limitations there. However, such provisions will only apply to new investments and actions taken after the plan is adopted. Such provisions are not corrective actions applicable to already existing forms of spatial development and heating sources already used.

One of the significant aspects of air protection is the spatial planning process and the need to improve the level of energy efficiency of urban layouts. Even though there is a methodology allowing for calculation of energy efficiency of buildings, it does not apply to cities or wider residential layouts, including suburban zones and the core of functional areas. However, the residential estate's localisation, transport systems and their equipment with technical and social infrastructure have a significant influence on energy consumption of the society living there and business entities operating there. Dispersion of buildings, lack of correlation between settlement development and technical infrastructure, including heating and gas networks, is favourable for dispersion of pollution emission sources and increases the surface emission. If energy consumption is multiplied within several years after the investment is implemented, it will result in such an amount of energy and a size of pollution that will have influence of exceeded allowable substances levels in the air. In addition, costs of such ineffective wat of power supply to a settlement system will be multiplied as well. Current attempts to estimate those costs and already established scientific methods have not been yet implemented in the planning system [23-25]. Another conclusion from the considerations above is that the level of energy efficiency of buildings and also of settlement systems, is responsible for high concentration of pollutions in the air. As it applies to the residential sector, it is also a justification for additional increase of emissions of, especially, benzo(a)pyrene and $\mathrm{PM}_{10}$ particulate matter.

As part of local activities, non-obligatory (from the legal point of view) local plans, programs of regeneration and low-carbon economy plans to be adopted in communes can become instruments supporting increased energy efficiency of buildings and functioning of entire housing estates. Those documents can be drawn by communes optionally; however, they are required in the process of applying for funds from the European Regional Development Fund as part of long-term operational programs. Thus, no financial support can be granted if there is no previous concept. Such a plan requires the commune to systematize its activities concerning low-carbon economy and can result in both new investments, changes to the current ways of functioning of the society and the economy in the commune.

Strategies for elimination of air pollution are based on three main fields of public intervention: activities targeted at limitation of emissions by production plants (point emission), elimination of pollution from the residential sector (low-stack emission) and development of public transportation together with minimization of car traffic (linear emission). According to the reports submitted by WIOS, the biggest challenge of all is the size of emissions generated in the residential sector. Point emissions elimination can be done via legal regulations applicable business entities; however, taking into account the experience of Germany, it should be predicted that the significance of the issue with linear emissions in Poland would increase in the future.

According to the statutory regulations, what is currently supposed to be Poland's most effective measures for the limitation of surface pollution is acts adopted by regional parliaments. Their aim is to introduce limitations and prohibitions concerning fuels and systems for their combustion within the territory of selected voivodeships (table 1). 
Table 1. The process of preparing the anti-smog resolution regarding the cities under study

\begin{tabular}{|c|c|c|c|}
\hline City & Voivodeship & Resolution status & $\begin{array}{l}\text { Development stage and the } \\
\text { territorial reference }\end{array}$ \\
\hline Cracow & $\begin{array}{l}\text { Lesser Poland } \\
\text { Voivodeship }\end{array}$ & Accepted & $\begin{array}{l}\text { The resolution adopted in two } \\
\text { stages, separately for the city of } \\
\text { Cracow and the rest of the province. }\end{array}$ \\
\hline Poznan & $\begin{array}{l}\text { Greater Poland } \\
\text { Voivodeship }\end{array}$ & $\begin{array}{l}\text { In the development, } \\
\text { horizon - the end of } 2017\end{array}$ & $\begin{array}{l}\text { Consultation with local } \\
\text { governments, the resolution will } \\
\text { cover the entire voivodeship. }\end{array}$ \\
\hline Warsaw & $\begin{array}{l}\text { Masovian } \\
\text { Voivodeship }\end{array}$ & $\begin{array}{l}\text { In the development, } \\
\text { horizon - the end of } 2017\end{array}$ & $\begin{array}{l}\text { Consultation with local } \\
\text { governments, the resolution will } \\
\text { cover the entire voivodeship. }\end{array}$ \\
\hline Wroclaw & $\begin{array}{l}\text { Lower Silesian } \\
\text { Voivodeship }\end{array}$ & $\begin{array}{l}\text { In the development, } \\
\text { horizon - the end of } 2017\end{array}$ & $\begin{array}{l}\text { Consultation with local } \\
\text { governments. Territorial differences } \\
\text { for city of Wroclaw, health resorts } \\
\text { and rest zones of the voivodeship. }\end{array}$ \\
\hline
\end{tabular}

\section{Summary}

The basic elements functioning in the urban air quality management system in Poland are constantly developed in compliance with (or aiming at compliance with) requirements referred to in applicable legal regulations. However, legal and coordination issues at the level of implementation of the area development policy should be improved. Environmental protection, including protection of ambient air, is seen as an activity limiting investment processes. Such an approach should be changed mainly by presenting the development policy as a policy improving the well-being of residents and ensuring good environmental situation.

Currently, the biggest difficulties in activities aiming at protection of ambient air are delegation of tasks to self-governments without and legal support at the national level, especially in case of emission requirements for combustion of fuels of power of up to 1 MW and admission of high emission fuels on the market. The current legal solutions also limit the possibilities of controlling natural persons. Voivodeship self-governments, which are responsible for preparation of ambient air protection programs, do not have any coercive means or financial support for communes. Works on coordination of those activities should cover issues within the scope of the structure of planning documents including mainly: ambient air protection programs, spatial developments plans in communes and voivodeships, low emission economy plans, plans of sustainable development of public transport, plans of providing heat, electric power and gas fuels to communes, acts of regional parliaments, introducing limitations based on the Environmental Protection Law and strategies of voivodeship development. The structure of coordination of the development policy should be made simpler and the voivodeship spatial development plan should be integrated with its development strategy. Then, strategic aims concerning air protection would gain a territorial dimension at the stage of their definition.

A key issue within the scope of air quality management in Poland is the need to change the basis of the power production paradigm in Poland from fossil fuels to other energy sources, including renewable ones, and to limit pollution emissions from road transport.

\section{References}

1. Review of evidence on health aspects of air pollution (REVIHAAP). Technical report. Copenhagen: WHO Regional Office for Europe 2013 
2. Health risk assessment of air pollution - general principles. Copenhagen: WHO Regional Office for Europe; 2016)A. Mecke, I. Lee, J.R. Baker jr., M.M. Banaszak Holl, B.G. Orr, Eur. Phys. J. E 14, 7 (2004)

3. Air quality in Europe - 2016 report, EEA Report No 28/2016

4. S. Gulia, S.M. Nagendra, M. Khare, I.Khanna, Atm. Poll. Res., 6, 286 (2015)

5. L. Duque, H. Relvas, C. Silveira, J. Ferreira, A. Monteiro, C. Gama, S. Rafael, S. Freitas, C. Borrego, A.I. Miranda, Atm. Environ. 127, 196 (2016)

6. A. Miranda, C. Silveira, J. Ferreira, A. Monteiro, D. Lopes, H. Relvas, C. Borrego, P. Roebeling,, Atm. Poll. Res. 6, 434 (2015)

7. Environmental Protection Act, Dz.U. (Polish Journal of Laws) No. 62 pos. 627 with subsequent amendments (2001)

8. Regulation of the Polish Minister of the Environment on the levels of certain substances in the air, Dz.U. pos. 1031 (2012)

9. B. Toczko in: Fine dust in the atmosphere. Compendium of Knowledge of Air Pollution from particulate matter in Poland (GIOŚ, Warsaw 2016, in Polish)

10. Regulation of the Polish Minister of the Environment on the assessment of levels of substances in the air, Dz.U. pos. 1032 (2012)

11. Directive of the European Parliament and of the Council on establishing a scheme for greenhouse gas emission allowance trading within the Community and amending Council Directive 96/61/EC, No. 2003/4/EC

12. Directive of the European Parliament and of the Council on ambient air quality and cleaner air for Europe (CAFE), No. 2008/50/UE

13. Regulation of the Polish Minister of the Environment on the way and frequency of updating environmental information, Dz.U. No. 227 pos. 1485 (2010)

14. D. Kobus, ENVIRON 34, 69 (2008)

15. J. Oleński, Information infrastructure of the state in the global economy (Department of Economics of Warsaw University, Warsaw 2006, in Polish)

16. http://powietrze.gios.gov.pl

17. http://sojp.wios.warszawa.pl,

18. http://air.wroclaw.pios.gov.pl

19. http://powietrze.poznan.wios.gov.pl

20. http://monitoring.Cracow.pios.gov.pl

21. http://www.um.warszawa.pl/aktualnosci/r-ne-aspekty-ochrony-powietrza-w-warszawie

22. Planning and Spatial Development Act, Dz.U. No. 80 pos. 717 (2003)

23. S. Czaja S., B. Fiedor in: Environmental aspects of the urban economy and new instruments in the urban management (University of Opole, Opole 2000, in Polish)

24. A. Kowalewski, J. Mordasewicz Konfederacja J. Osiatyński, J. Regulski, J. Stępień P., Report on economic loss and social costs of uncontrolled urbanization in Poland (Institute of Geography and Spatial Sciences (GaSSI) of PAS, Warsaw 2013, in Polish)

25. P. Śleszyński P., M Andrzejewska, D. Cerić, A. Deręgowska, T. Komornicki, M. Rusztecka, J. Solon, P. Sudra, B. Zielińska, Analysis of the status and conditions of planning work in municipalities in 2014. (GaSSI of PAS, Warsaw 2016, in Polish) 